\title{
Clinical experience with technetium-99m stannous polyphosphate for myocardial imaging
}

\author{
Lawrence A. Gould, Louis A. Perez, David B. Hayt, C. V. R. Reddy, Charles Blatt, and \\ Robert F. Gomprecht, with the technical assistance of Ronald Urioste \\ From the Department of Medicine and Radiology, Misericordia Hospital Medical Center, Bronx, New \\ York, U.S.A.
}

Myocardial imaging with technetium-99m stannous polyphosphate was performed on 46 patients. Elevєn patients had no cardiac disease, 22 had acute myocardial infarction, and 13 had stable arteriosclerotic heart disease.

Distinct patterns of myocardial activity were noted: (1) the patients with no obvious cardiac disease showed no cardiac activity; (2) stable arteriosclerotic heart disease showed faint, ill-defined cardiac activity, primarily in the anterior or inferior aspect of the left ventricle; (3) acute myocardial infarction showed intense, focal, well-defined activity, with a shape that characterized the location of the infarct.

Various centres are working to establish a method to estimate the size of a myocardial infarction. ST segment mapping (Maroko et al., 1972) and determination of the isoenzymes of creatine phosphokinase (Sobel et al., 1972) are two currently used investigative tools.

Recently, some workers have found that it is possible to use radioactive materials to detect the infarcted area (Gorten et al., 1966; Hubner, 1970). Further a radio indicator sequestered by acute infarcted myocardium would also allow an estimation of the size of the infarction. Most of the techniques used in the past depended on failure of the ischaemic myocardium to take up the radionuclide, with a resultant negative image or a 'cold area'. Caesium129 (Romhilt et al., 1973), caesium-131 (Carr et al., 1964), caesium-134 (Chandra et al., 1973), rubidium-81 (Martin et al., 1974), nitrogen-13 (Harper et al., 1973), potassium-42 (Bennett et al., 1972), potassium-43 (Zaret et al., 1973), and radiolabelled fatty acids (Evans et al., 1965), are radionuclides which provide this negative image. However, these materials cannot distinguish a recent from an old myocardial infarction and the physical and biological characteristics of these pharmaceuticals limit their clinical usefulness in detecting the infarcted tissue.

Bonte et al. (1974) have reported that technetium$99 \mathrm{~m}$ stannous pyrophosphate can localize in the Received 18 December 1975. myocardium of dogs which have had experimentally produced myocardial infarction. Since the radionuclide accumulates in the necrotic area, it shows the lesion as an area of increased radioactivity, or as a hot spot.

In order to assess the clinical applicability of this new test, the following study was designed.

\section{Subjects and methods}

Forty-six patients were studied, 11 of whom had no cardiac disease. The patients presented with chest pain and scintigrams were performed to rule out a myocardial infarction. Twenty-two patients had an acute myocardial infarction with typical history, electrocardiogram, and enzyme changes. Seven had subendocardial infarction and the remaining 15 a transmural infarction. The age of these 22 patients ranged from 47 to 86 (mean 60 ) years. Fourteen of the patients were men. Seven of the patients with an acute myocardial infarction had repeat scintigrams performed.

All 13 patients with stable arteriosclerotic heart disease presented with chest pain and had preexistent angina or an old myocardial infarction. A new myocardial infarction was subsequently not proven by serial electrocardiograms and enzyme studies. Their ages ranged from 36 to 87 (mean 63) years. Six patients were men.

Technetium-99m stannous polyphosphate, $15 \mathrm{~m}$ 
$\mathrm{Ci}$, was administered intravenously to each patient. The polyphosphate is manufactured by New England Nuclear Corporation. Two chains are present in this product. This isotope has a half-life of 6 hours which allows repetition of the study every 24 hours. In acutely ill patients the radioactive material was transported to the patient's bedside in an appropriate lead-lined safe, designed for carrying syringes. Sixty minutes later, left anterior and left lateral scintiphotos of the upper thorax were obtained. A high resolution colimator, $140 \mathrm{Kev}$, was centred at the point of maximal cardiac pulsation for both views. There were 300000 counts per scintiphoto with a 20 per cent window. A Nuclear Chicago gamma camera was used to obtain the images. The images were recorded both on a Polaroid format and a $35 \mathrm{~mm}$ format. The $35 \mathrm{~mm}$ format is favoured since the areas of increased activity are more dramatically portrayed.

The patients suspested of having an acute myocardial infarction were accompanied to the Nuclear Medicine Laboratory with appropriate resuscitators, life support equipment, monitors, and in the presence of a trained intensive care unit nurse, medical resident, and intern. No patient was examined if the clinical condition was not considered stable by the cardiology group. The patient was not transferred from the stretcher for the examination, and it was not nesessary to move the patient's body. The only necessary movement was to allow the patient's left arm to be extended above shoulder level while he lay supine. The arm was supported in this position for two minutes in order to obtain the left lateral scintiphoto. The total time necessary for the patient to remain in the Nuclear Medicine Laboratory for a complete examination, including positioning, recording, developing film, and provisional diagnosis, was approximately 12 minutes.

Fifty-three myocardial scans were obtained in the 46 subjects. Informed consent was obtained from all the patients.

\section{Results}

Tables 1 to 3 tabulate the clinical information and the scan results on the 46 patients. No myocardial activity was found in the 11 patients without obvious heart disease (Fig. 1).

The patients with stable arteriosclerotic heart disease were studied 2 to 20 days after the onset of symptoms (mean 8.6 days). All but one of these patients had studies which showed faint, ill-defined activity, primarily in the anterior or inferior aspect of the left ventricle (Fig. 2). The acute myocardial infarction patients had images obtained 2 to 18 days after the onset of the infarct (mean $6 \cdot 1$ days). All these patients had intense, focal, well-defined increased activity in the region corresponding to the electrocardiographic localization of the infarction. A typical ' $C$ ' shaped zone of intense activity was seen in the anterior wall myocardial infarctions (Fig. 3) and a plate-like zone of increased activity was seen in the inferior wall myocardial infarction (Fig. 4).

Seven of the patients with an acute myocardial

TABLE 1 Patients without arteriosclerotic heart disease

\begin{tabular}{|c|c|c|c|c|c|c|c|c|c|c|}
\hline Patient & Age & Sex & $\begin{array}{l}\text { Chest } \\
\text { pain }\end{array}$ & Discharge diagnosis & $E C G$ & $\begin{array}{l}\text { Highe } \\
\text { AST }\end{array}$ & st $C K$ & $L D H$ & Scan & $\begin{array}{l}\text { Scan } \\
\text { days after } \\
\text { admission }\end{array}$ \\
\hline FD & 69 & $\mathbf{M}$ & + & Carcinoma of prostate & Normal & 20 & 85 & 245 & No activity & 21 \\
\hline RA & 41 & $\mathbf{F}$ & + & Carcinoma of tonsillar fossa & Normal & 15 & 50 & 280 & No activity & 4 \\
\hline $\mathrm{CC}$ & 69 & $\mathbf{M}$ & + & Carcinoma of bladder & Normal & 20 & 60 & 100 & No activity & 5 \\
\hline $\mathrm{J} M$ & 50 & $M$ & + & Hypertension & $\begin{array}{l}\text { Non-spec. ST-T wave } \\
\text { changes }\end{array}$ & 20 & 35 & 240 & No activity & 4 \\
\hline JD & 62 & $\mathbf{M}$ & + & Carcinoma of lung & Normal & 20 & 140 & 275 & No activity & 9 \\
\hline CA & 42 & $\mathbf{F}$ & + & Metastatic carcinoma & Normal & 10 & 70 & 200 & No activity & 5 \\
\hline EP & 63 & $\bar{M}$ & + & $\begin{array}{l}\text { Rheumatic heart disease; } \\
\text { mitral insuff. }\end{array}$ & $\begin{array}{l}\text { Non-spec. ST-T wave } \\
\text { changes }\end{array}$ & 20 & 35 & 245 & No activity & 5 \\
\hline LP & 48 & $M$ & + & Acute pericarditis & $\begin{array}{l}\text { Non-spec. ST-T wave } \\
\text { changes }\end{array}$ & 30 & 110 & 300 & No activity & 4 \\
\hline CG & 53 & $\mathbf{M}$ & + & Carcinoma of lung & Normal & 9 & 65 & 255 & No activity & 5 \\
\hline AR & 18 & $\mathbf{M}$ & + & Duodenal ulcer & Normal & 15 & 70 & 250 & No activity & 6 \\
\hline AS & 65 & $\mathbf{M}$ & + & Syncope & $\begin{array}{l}\text { Non-spec. ST-T wave } \\
\text { changes }\end{array}$ & 23 & 220 & 245 & No activity & 5 \\
\hline
\end{tabular}

Normal enzyme values $=$ AST 7-40 units, LDH $150-400$ units, CK 0-130 units.

Note : $\mathrm{AST}=$ aspartate aminotransferase; $\mathrm{CK}=$ creatine kinase; $\mathrm{LDH}=$ lactic dehydrogenase. 
TABLE 2 Patients with arteriosclerotic heart disease

\begin{tabular}{|c|c|c|c|c|c|c|c|c|c|c|}
\hline Patient & Age & Sex & $\begin{array}{l}\text { Chest } \\
\text { pain }\end{array}$ & Condition & $E C G$ & $\begin{array}{l}\text { Highest } \\
A S T\end{array}$ & $C K$ & $L D H$ & Scan & $\begin{array}{l}\text { Scan } \\
\text { days after } \\
\text { admission }\end{array}$ \\
\hline AG & 62 & $\mathbf{M}$ & + & Angina & $\begin{array}{l}\text { Old anterior wall myocardial } \\
\text { infarction }\end{array}$ & 30 & 55 & 305 & Faint activity & 14 \\
\hline NS & 36 & $\mathbf{M}$ & + & Angina & $\begin{array}{l}\text { Non-spec. ST-T wave } \\
\text { changes }\end{array}$ & 15 & 75 & 220 & $\begin{array}{l}\text { Faint ill defined } \\
\text { activity }\end{array}$ & 3 \\
\hline WS & 56 & $M$ & + & Angina & $\begin{array}{l}\text { Non-spec. ST-T wave } \\
\text { changes }\end{array}$ & 22 & 55 & 250 & Faint activity & 3 \\
\hline MC & 72 & $\mathbf{F}$ & + & 一 & Old inferior wall MI & 20 & 60 & 200 & Faint activity & 3 \\
\hline BC & 87 & $\mathbf{M}$ & + & Angina & $\begin{array}{l}\text { Non-spec. interventricular } \\
\text { conduction defect }\end{array}$ & 33 & 60 & 185 & Faint activity & 3 \\
\hline FW & 60 & $\mathbf{M}$ & + & 一 & Old anteroseptal & 23 & 115 & 390 & Faint activity & 5 \\
\hline EL & 75 & $\mathbf{F}$ & + & Angina & $\begin{array}{l}\text { Non-spec. ST-T wave } \\
\text { changes }\end{array}$ & 34 & 60 & 350 & Faint activity & 14 \\
\hline VW & 59 & $\mathbf{F}$ & + & - & Left bundle-branch block & 56 & 110 & 390 & Faint activity & 20 \\
\hline CM & 71 & $\mathrm{~F}$ & + & Angina & Right bundle-branch block & 40 & 140 & 295 & Faint actıvity & 9 \\
\hline NL & 48 & $\mathbf{M}$ & + & - & Old anterior wall & 14 & 70 & 260 & Faint activity & 2 \\
\hline HR & 58 & $\mathrm{~F}$ & + & Angina & $\begin{array}{l}\text { Non-spec. ST-T wave } \\
\text { changes }\end{array}$ & 24 & 95 & 240 & Faint activity & 16 \\
\hline MB & 81 & $\mathbf{F}$ & + & $\begin{array}{l}\text { Congestive } \\
\text { heart failure }\end{array}$ & Left ventricular hyper. & 27 & 165 & 290 & No actıvity & 15 \\
\hline $\mathbf{R F}$ & 54 & $\mathbf{F}$ & + & - & Old anteroseptal $\mathrm{MI}$ & 24 & 65 & 340 & Faint activity & 5 \\
\hline
\end{tabular}

For abbreviations, see Table 1.

TABLE 3 Patients with acute myocardial infarction

\begin{tabular}{|c|c|c|c|c|c|c|c|c|}
\hline Patient & Age & Sex & ECG location & $\begin{array}{l}\text { Highes } \\
\text { AST }\end{array}$ & ${ }^{s t} C K$ & $L D H$ & Scan & $\begin{array}{l}\text { Days } \\
\text { after } \\
\text { infarct }\end{array}$ \\
\hline WN & 64 & $\mathbf{M}$ & $\begin{array}{l}\text { Right bundle-branch block; } \\
\text { anterior subendocardial MI }\end{array}$ & 66 & 635 & 315 & Focal increased activity-anterior & 9 \\
\hline MJ & 43 & $\mathbf{M}$ & Anterior subendocardial MI & 50 & 300 & 445 & Focal increased activity一anterior & 7 \\
\hline $\mathrm{CV}$ & 63 & $\mathbf{F}$ & Anterior wall MI & 225 & 1425 & 1000 & Focal increased activity - anterior & 2 \\
\hline MM & 61 & $\mathbf{F}$ & Anterior subendocardial $\mathrm{MI}$ & 108 & 800 & 470 & Focal increased activity-anterior & 9 \\
\hline MG & 62 & $\mathbf{M}$ & Inferior subendocardial MI & 62 & 435 & 410 & Focal increased activity-inferior & 3 \\
\hline WD & 63 & $\mathbf{M}$ & $\begin{array}{l}\text { Old inferior wall; new anterior } \\
\text { subendocardial MI }\end{array}$ & 35 & 175 & 330 & $\begin{array}{l}\text { Broad area activity, anterior and } \\
\text { inferior }\end{array}$ & 7 \\
\hline $\mathrm{JL}$ & 68 & $\mathbf{M}$ & Old inferior wall; new anteroseptal & 70 & 400 & 375 & Focal increased activity - anterior & 2 \\
\hline $\mathrm{CD}$ & 86 & $\mathbf{F}$ & Anterior wall MI & 56 & 290 & 495 & Focal increased activity-anterior & 3 \\
\hline US & 73 & $\mathbf{M}$ & Inferior wall $\mathrm{MI}$ & 60 & 340 & 425 & Focal increased activity-inferior & 3 \\
\hline PT & 62 & $\mathbf{M}$ & Inferior wall MI & 286 & 2575 & 650 & Focal increased activity-inferior & 18 \\
\hline RF & 63 & $\mathbf{F}$ & Anterior wall MI & 156 & 1470 & 950 & Focal increased activity-anterior & 9 \\
\hline WJ & 47 & $\mathbf{M}$ & Anterolateral wall $\mathrm{MI}$ & 510 & 4700 & 1170 & Focal increased activity - anterior & 11 \\
\hline GS & 48 & $\mathbf{F}$ & Anterolateral subendocardial MI & 33 & 270 & 335 & Focal increased activity-anterolateral & 5 \\
\hline MG & 68 & $\mathbf{F}$ & Anterior wall MI & 45 & 480 & 395 & Focal increased activity - anterior & 10 \\
\hline EV & 74 & $\mathbf{F}$ & $\begin{array}{l}\text { Old inferior wall } \mathrm{MI} \text {; new inferior } \\
\text { wall } \mathrm{MI}\end{array}$ & 60 & 200 & 400 & Focal increased activity-inferior & 4 \\
\hline $\mathbf{D N}$ & 72 & $\mathbf{M}$ & Anterior wall $\mathrm{MI}$ & 50 & 180 & 425 & Focal increased activity-anterior & 3 \\
\hline LS & 55 & $\mathbf{M}$ & Anterior wall MI & 37 & 305 & 320 & Focal increased activity-anterior & 6 \\
\hline SD & 64 & $\mathbf{M}$ & $\begin{array}{l}\text { Old inferior wall; new anterior } \\
\text { wall MI }\end{array}$ & 198 & 1440 & 640 & Focal increased activity - anterior & 3 \\
\hline HR & 69 & $\mathbf{M}$ & Inferior MI & 125 & 860 & 570 & Focal increased activity-inferior & 5 \\
\hline JB & 56 & $\mathbf{M}$ & Anteric $\mathrm{r}$ - subendocardial MI & 24 & 610 & 270 & Focal increased activity-anterior & 9 \\
\hline $\mathrm{CM}$ & 62 & $\mathbf{F}$ & Anterior wall $\mathrm{MI}$ & 50 & 200 & 375 & Focal increased activity -anterior & 3 \\
\hline LH & 60 & $\mathrm{M}$ & Inferior wall $\mathrm{MI}$ & 60 & 330 & 450 & Focal increased activity-inferior & 4 \\
\hline
\end{tabular}


infarction (Table 4) had repeat scintigrams performed 14 to 32 days after the initial onset of symptoms (mean 22 days). Four of these follow-up studies showed less activity in the myocardium than the initial scintigrams. In these patients the enzymes had returned to normal values and the electrocardiogram had stabilized.
Three patients showed an increase in activity and a larger area of involvement. These patients also had clinical evidence of extension based on a new bout of chest pain, an increase in enzymes, and characteristic electrocardiographic abnormalities (Fig. 5 and 6).
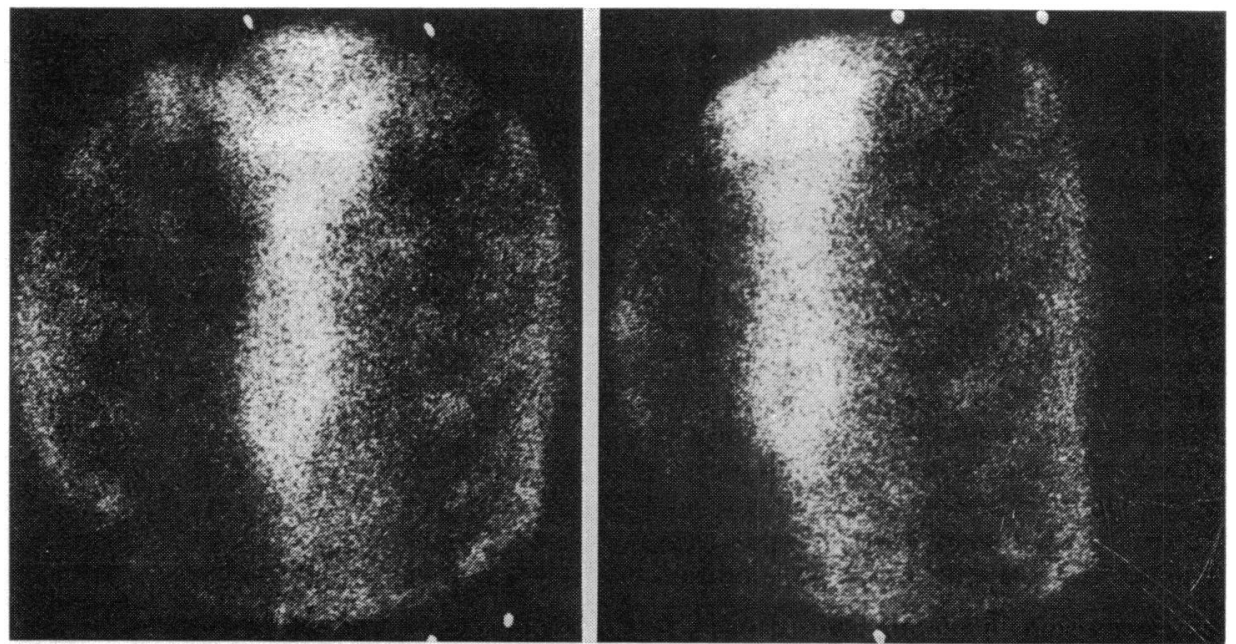

FIG. 1 Anterior and left lateral scintiphotos of patient $A R$, with no cardiac disease. The ribs and sternum are well seen. There is no cardiac activity.
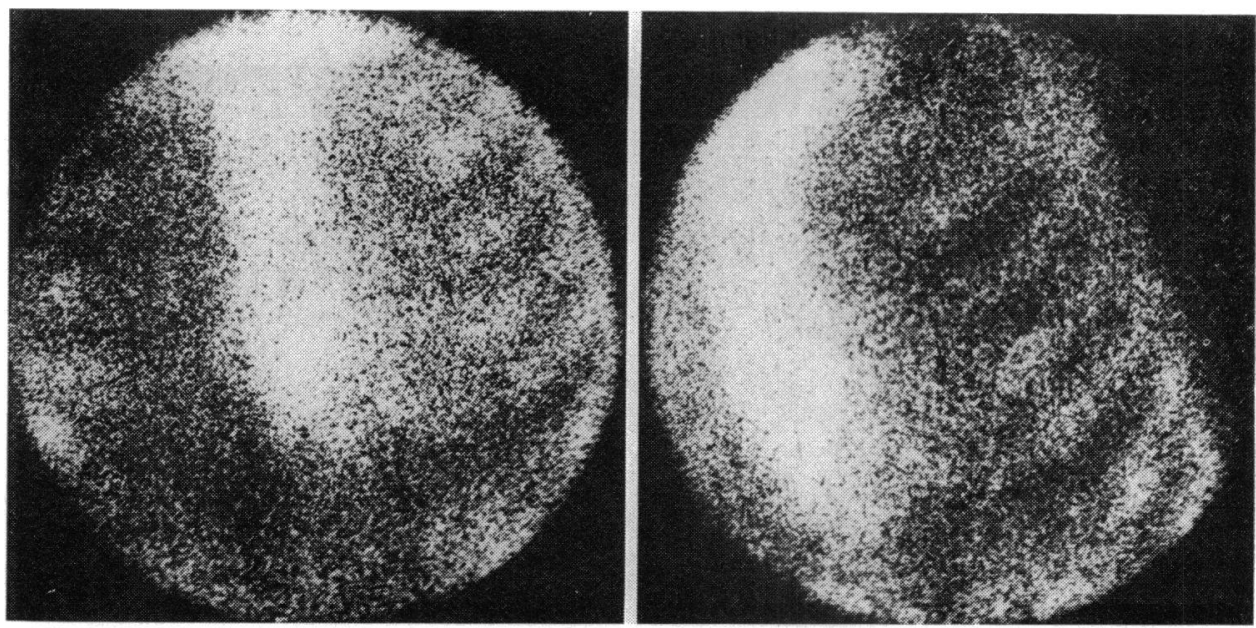

FIG. 2 Anterior and left lateral scintiphotos in patient FW, with stable arteriosclerotic heart disease. Note the faint ill-defined activity. 


\section{Discussion}

Bonte et al. (1974) determined that ${ }^{99} \mathrm{~m}$ Tc-stannous pyrophosphate can localize in the hearts of dogs with experimentally produced myocardial infarction. These authors suggested that with myocardial cell death there was a cellular influx of calcium ions which localized within the mitochondria in the crystalling structure hydroxyapatite. Since $99 \mathrm{mTc}-$ stannous pyrophosphate labels hydroxyapatite for bone scanning, this isotope can also image fresh myocardial infarctions on the basis of the hydroxyapatite content. Other possible mechanisms in- clude binding of phosphate to damaged cell membranes, uptake in other cytoplasmic or nuclear organelles, or binding to leucocytes invading the infarcted area.

Subsequently the same group performed myocardial scans on 15 patients with acute myocardial infarction (Parkey et al., 1974). Thirteen patients had scans 3 to 7 days after the infarction and these were strongly positive in the regions corresponding to the electrocardiographic localization of the infarction. The remaining 2 patients were scanned more than 9 days after the infarction and their scans were negative. They also studied 2 patients with
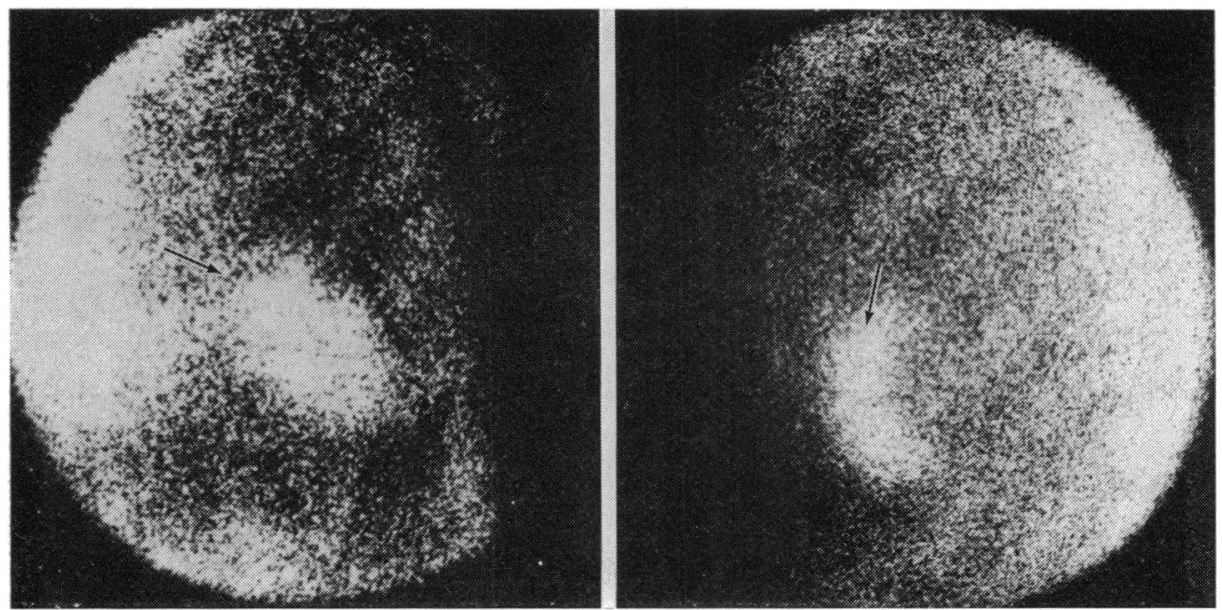

FIG. 3 Anterior and left lateral scintiphotos in patient WN, with an acute anterior wall myocardial infarction. Note the ' $C$ ' shaped zone of intense activity in the lateral view.
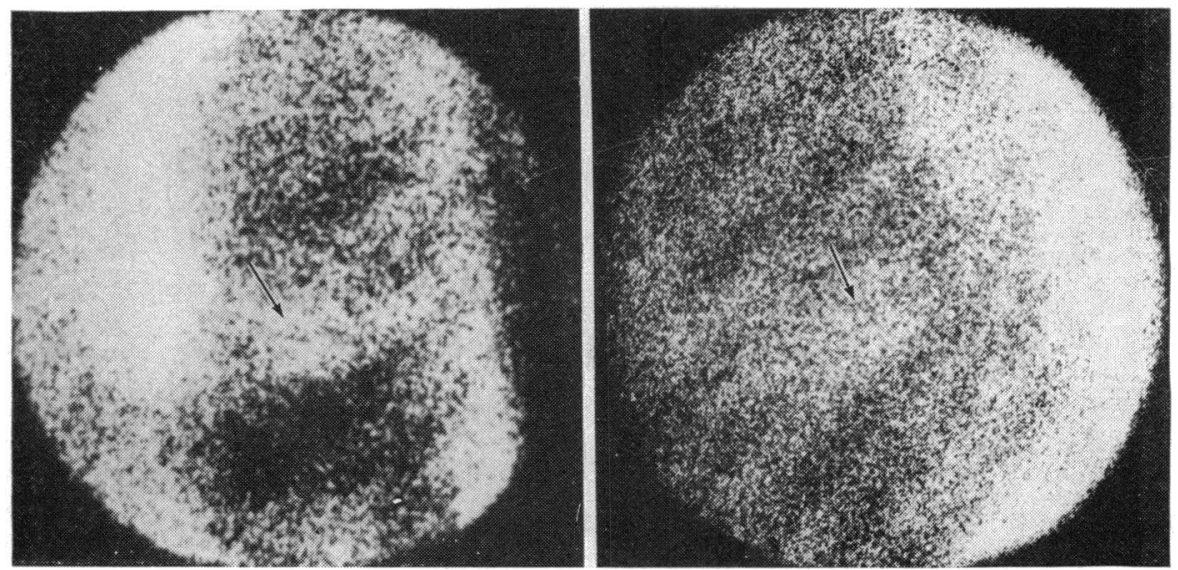

FIG. 4 Anterior and left lateral scintiphotos in patient US, with an inferior wall myocardial infarction. Note the plate like zone of increased activity. 
stable arteriosclerotic heart disease and found questionable activity in their scintigrams.

Our present study supports and extends these observations. An acute myocardial infarction can be detected as early as 2 days and as late as 10 days after the infarction. Two patients in our study had positive scans 11 and 18 days after the onset of symptoms. However, they also had the highest CK values, which may explain the persistent activity. The myocardial activity is localized in the areas corresponding to the electrocardiographic abnormalities. Further, a characteristic ' $C$ ' shape zone of intensive activity was found in the anterior wall myocardial infarction while a plate-like zone of activity was found in the inferior wall myocardial infarction. Normal individuals show no cardiac activity. However, patients with stable arteriosclerotic heart disease do show faint ill-defined cardiac activity in the anterior or inferior aspect of the left ventricle. The exact reason that these scintigrams were faintly positive in these patients is uncertain, but several possibilities deserve mention. The positive scintigrams might indicate that there is a continual loss of small diffuse amounts of myocardial tissue caused by repeated bouts of myocardial ischaemia, or there may have been a
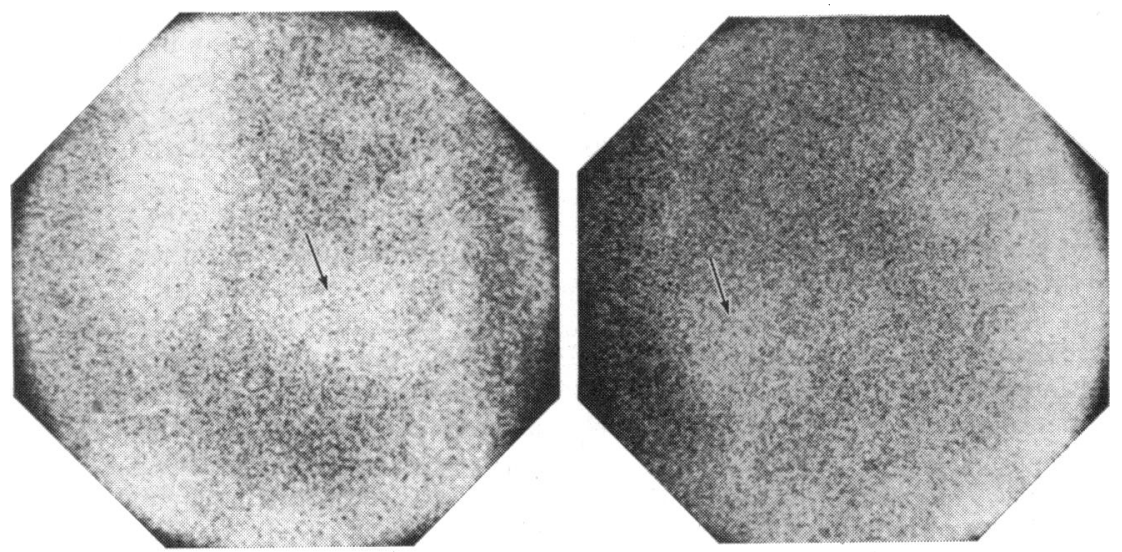

FIG. 5 Anterior and left lateral scintiphotos in patient SD obtained 3 days after his anterior wall infarction. These photos are copies of the polaroids. Thus, the area of isotope uptake is white on a black background.


FIG. 6 A repeat scintiphoto obtained 18 days after the infarction now shows a larger area of involvement. 
myocardial infarction in the distant past. However, it is very easy to separate the acute myocardial infarction with the focal intense activity from the minimal, non-focal cardiac activity seen in the stable arteriosclerotic patients.

Willerson et al. (1975) also administered technetium-99m stannous pyrophosphate to 17 patients with electrocardiographic and enzymatic evidence of an acute subendocardial myocardial infarction. In each patient the scintigrams were positive. However, it was not possible accurately to localize the area of myocardial damage in many of their patients. This is in contrast to the ability to localize fairly precisely the area of damage in transmural myocardial infarctions.

Botvinick et al. (1975) produced infarctions in 6 closed chest dogs. Scintiphotographs were taken 48 hours after the occlusion using technetium-99m pyrophosphate. Clear images of the infarction were obtained which correlated well with electrocardiographic localization. The animals were sacrificed and significant radioactivity was found only in regions of histologically confirmed infarction. Further the isotope localized specifically in areas of infarcted myocardium in amounts proportional to the degree of CK depletion. The authors concluded that these data provide strong support for the clinical application of this technique in the detection and quantification of acute myocardial infarction.

Willerson et al. (1975) have also subsequently reported in a larger series of patients that infarct size can be estimated from technetium-99m stannous pyrophosphate scintigrams. These authors are still not certain that some ischaemic but not necessarily irreversibly damaged cells may also label with technetium-99m pyrophosphate.

Bonte and his associates used technetium-99m stannous pyrophosphate for their studies. This agent is now limited to investigational use, while the ${ }^{99} \mathrm{~m} \mathrm{Tc}$-stannous polyphosphate is widely available. Both agents appear to give diagnostic scintigrams 60 minutes after the injection of the radionuclide. Further studies will be required to assess the relative merits of these two agents.

This new imaging technique can help to distinguish between an acute myocardial infarction and other conditions that cause chest pain. It may assist the surgeon by delineating precisely the area of damaged myocardium that may require operative intervention. It can detect an extension of the myocardial infarction. Most importantly, these tests can be carried out without danger or discomfort to the critically ill patient. Particularly if the institution is equipped with mobile scintillation cameras. The tracer is safe, inexpensive, and almost universally available.

Tetracycline labelled with ${ }^{99} \mathrm{~m} \mathrm{Tc}$ can also detect a myocardial infarction as a 'hot' spot (Holman et al., 1974). However, the optimal time for the scintiscan study using tetracycline labelled radionuclide is one to three days after the onset of chest pain. After three days little or no cardiac activity is observed. This contrasts with the ${ }^{99} \mathrm{~m} \mathrm{Tc}$ polyphosphate studies. Positive scans can be obtained more than two weeks after the infarction. Further, the tetracycline labelled radionuclide produces a high uptake in the liver, resulting in difficulty in sizing diaphragmatic infarcts. Other radionuclides are currently being investigated. Technetium-99m

TABLE 4 Myocardial infarction patients with follow-up scintigrams

\begin{tabular}{|c|c|c|c|c|c|}
\hline Patient & First scan & $\begin{array}{l}\text { Days after } \\
\text { infarction }\end{array}$ & Second scan & $\begin{array}{l}\text { Days after } \\
\text { infarction }\end{array}$ & Comment \\
\hline HR & Focal increased activity-inferior & 5 & Less activity一inferior & 14 & \\
\hline LS & Focal increased activity-anterior & 6 & Less activity-anterior & 26 & \\
\hline GS & Focal increased activity-anterolateral & 5 & No activity & 25 & \\
\hline JM & Focal increased activity-anterior & 7 & $\begin{array}{l}\text { Increased activity } \\
\text { larger area }\end{array}$ & 14 & $\begin{array}{l}8 \text { days after infarction-chest } \\
\text { pain, enzyme rise, } \\
\text { anterior transmural } \mathrm{MI}\end{array}$ \\
\hline SD & Focal increased activity-anterior & 3 & $\begin{array}{l}\text { Increased activity larger } \\
\text { area-anterior }\end{array}$ & 18 & $\begin{array}{l}15 \text { days after infarction-chest } \\
\text { pain, enzyme rise, } T \text {-wave } \\
\text { inversion in praecordial } \\
\text { lead }\end{array}$ \\
\hline CV & Focal increased activity-anterior & 2 & $\begin{array}{l}\text { More extensive involve- } \\
\text { ment-anterior }\end{array}$ & 26 & $\begin{array}{l}10 \text { days after infarction-chest } \\
\text { pain, enzyme rise, } T \text {-wave } \\
\text { inversion in praecordial } \\
\text { leads }\end{array}$ \\
\hline MM & Focal increased activity-anterior & 9 & $\begin{array}{l}\text { Minimal persistent } \\
\text { activity }\end{array}$ & 32 & \\
\hline
\end{tabular}


glucoheptonate has been found to be localized in areas of acutely infarcted myocardium in animals as well as in humans. Strauss et al. (1975) found that there was a good correlation between peak CK values and the percentage of the left ventricular area accumulating this isotope. Kramer et al. (1974) have reported that gallium-67 citrate can accumulate selectively in recently infarcted canine myocardium: the infarction appears as a hot zone. Gallium enters or is retained within the infarcted region as a result of the inflammatory cell response to the ischaemic cell damage.

Myocardial scanning appears to be a valuable technique for establishing the presence or absence of a myocardial infarction. These studies should be extended to gain more information about this new and promising test.

\section{References}

Bennett, K. R., Smith, R. O., Lehan, P. H., and Hellems, H. K. (1972). Correlation of myocardial ${ }^{42} \mathrm{~K}$ uptake with coronary arteriography. Radiology, 102, 117.

Bonte, F. J., Parkey, R. W., Graham, K. D., Moore, J., and Stokely, R. (1974). A new method of radionuclide imaging of myocardial infarcts. Radiology, 110, 473.

Botvinick, E., Lappin, H., Townsend, R., Shames, D., Tyberg, J., and Parmley, W. (1975). Noninvasive quantitiacion of myocardial infarction with $99 \mathrm{~m} \mathrm{Tc}(\mathrm{Sn})$ pyrophosphate: correlation between creatine phosphokinase depletion and radionuclide uptake. American fournal of Cardiology, 35, 123.

Carr, E. A., Gleason, G., Shaw, J., and Krontz, B. (1964). The direct diagnosis of myocardial infarction by photoscanning after administration of cesium-131. American Heart fournal, 68, 627.

Chandra, R., Braunstein, P., Streuli, F., and Hirsch, J. (1973). $134 \mathrm{~m} C s$, a new myocardial imaging agent. fournal of Nuclear Medicine, 14, 243.

Evans, J. R., Gunton, R. W., Baker, R. G., Beanlands, D. S., and Spears, J. C. (1965). Use of radio-icdinated fatty acid for photoscans of the heart. Circulation Research, 16, 1.

Gorten, R. J., Hardy, L. B., McCraw, B. H., Stokes, J. R., and Lumb, G. D. (1966). The selective uptake of $\mathrm{Hg}^{2203}$ chlormerodrin in experimentally produced myocardial infarcts. Americar Heart fournal, 72, 71.

Harper, P. V., Schwartz, J., Beck, R. N., Lathrop, K. A., Lembares, I. V., Krizek, H., Gloria, I., Dinwoodie, R., McLaughlin, A., Stark, V. J., Bekerman, C., Hoffer, P. B.,
Gottschalk, A., Resnekov, L., Al-Sadir, J., Mayorga, A., and Brooks, H. L. (1973). Clinical myocardial imaging with nitrogen-13 ammonia. Radiology, 108, 613.

Holman, B. I.., Lesch, M., Zweiman, F., Temte, J., Dewangee, M. K., Lown, B., and Gorlin, R. (1974). Evaluation of acute myocardial infarction with technetium-99mtetracycline infarct imaging. American fournal of Cardiology, 33, 144.

Hubner, P. J. B. (1970). Radioisotopic detection of experimental myocardial infarction using mercury derivatives of fluorescein. Cardiovascular Research, 4, 509.

Kramer, R. J., Goldstein, R. E., Hirshfeld, J. W., Jr., Roberts, W. C., Johnston, G. S., and Epstein, S. E. (1974). Accumulation of Gallium-67 in regions of acute myocardial infarction. American fournal of Cardiology, 33, 861.

Maroko, P. R., Libby, P., Covell, J. W., Sobel, B. E., Ross, J., Jr., and Brunwald, E. (1972). Precordial S-T segment elevation mapping: an atraumatic method for assessing alterations in the extent of myocardial ischemic injury. American fournal of Cardiology, 29, 223.

Martin, N. D., Zaret, B. L., McGowan, R. L., Wells, H. P., Jr., and Flamm, M. D. (1974). Rubidium-81: a new myocardial scanning agent. Radiology, 111, 651.

Parkey, R. W., Bonte, F. J., Meyer, S. I.,, Atkins, J. M., Curry, G. L., Stokely, E. M., and Willerson, J. T. (1974). A new method for radionuclide imaging of acute myocardial infarction in humans. Circulation, 50, 540.

Romhilt, D. W., Adolph, R. J., Sodd, V. J., Levenson, N. I., August, L. S., Nishiyama, H., and Berke, R. A. (1973). Cesium-129 myocardial scintigraphy to detect myocardial infarction. Circulation, 48, 1242.

Sobel, B. E., Bresnahan, G. F., Shell, W. E., and Yoder, R. D. (1972). Estimation of infarct size in man and its relation to prognosis. Circulation, 46, 640.

Strauss, H. W., Rouleau, J., Rossman, D., and Pitt, B. (1975). Detection of acute myocardial infarction in patients with technetium 99-m glucoheptonate. American fournal of Cardiology, 35, 171.

Willerson, J. T., Parkey, R. W., Bonte, F. J., Meyer, S. L., and Stokely, E. M. (1975). Acute subendocardial myocardial infarction in patients. Its detection by Technetium 99-m stannous pyrophosphate myocardial scintigrams. Circulation, 51, 436.

Zaret, B. L., Strauss, H. W., Martin, N. D., Wells, H. P., Jr., and Flamm, M. D., Jr. (1973). Noninvasive regional myocardium perfusion with radioactive potassium. Study of patients at rest, with exercise and during angina pectoris. New England fournal of Medicine, 288, 809.

Requests for reprints to Dr. Lawrence A. Gould, The Methodist Hospital, 506 Sixth Street, Brooklyn, N.Y. 11215, U.S.A. 